\title{
Process of Economic Terms Internationalization (By Materials of the German, Russian and Tatar Languages)
}

\author{
Alfiya N. Zaripova ${ }^{1} \&$ Anna D. Fominykh ${ }^{1}$ \\ ${ }^{1}$ Kazan (Volga Region) Federal University, Kazan, Russia \\ Correspondence: Alfiya N. Zaripova, Kazan (Volga Region) Federal University, Kremlyovskaya Street, 18, \\ Kazan 420008, Russia. E-mail: alfija_kazan@hotmail.com
}

\author{
Received: April 14, 2015 Accepted: April 20, 2015 Online Published: April 27, 2015 \\ doi:10.5539/jsd.v8n4p112 URL: http://dx.doi.org/10.5539/jsd.v8n4p112
}

\begin{abstract}
The paper presents the characteristics of internationalisms in the economic terminology of German, Russian and Tatar languages. The emergence of borrowings in economic terminology is stimulated by the process of globalization, and is the result of cooperation between the countries. Successful achievements in this field are the property of many countries. Borrowings in the economic sphere are international, possible to be allocated into comparable and non-comparable areas. The emergence of non-comparable area in the studied languages is due to cultural and historical conditions of their functioning. In the process of using international vocabulary the issues of semantic inaccuracy and irrational use of words may arise. All borrowed lexemes are subject to formal and functional assimilation in languages. Materials research can be used in the teaching of German, Russian and Tatar languages, as well as in the teaching of subjects such as Terminology, comparative linguistics and lexicology.
\end{abstract}

Keywords: terminology system, term, internationalism, borrowing

\section{Introduction}

\subsection{The Importance of the Problem}

The modern geopolitical and socio-cultural situation in the world encourages the development and extension of international contacts, strengthening of multilateral cooperation between nations, which inevitably leads to the need to improve the transmission and processing of information, unification of certain areas of knowledge, particularly economic one. Economic terminology system is one of the most dynamic and rapidly developing, so the issues of globalization affect primarily this area. Some economic realities have a pronounced international character, for example, the system of customs control, the terms of foreign trade and others. As a result of any contact in the terminology system of the national language arise borrowed lexical units. "The more one or another field of activity is involved in international cooperation, in more or less long-term international relations, the more the vocabulary and terminology of the sphere is open to foreign language innovation" (Krysin, 2008).

The borrowing of foreign words is a historical process, resulting from the constant and comprehensive communication between nations, and can operate in one borrowing language. "If the subject-semantic diversity of borrowed words is very large, the range of international terms is narrower than the range of loanwords, and they penetrate in national languages only as a result of cultural and historical exchange between nations" (Belchikov, 1959). In addition, the "internationalisms present "reasonable" borrowings" (Belchikov, 1959).

Thus in economic terms of the Russian and Tatar languages borrowed concepts became particularly widespread in the $90 \mathrm{~s}$ as a result of socio-economic changes in our country. Borrowing vocabulary from languages with established and stable economic terminology represents one of the options to meet the needs. On the other hand, economic thought and forms of economic activity and management are in constant development, and their successful implementation and the impact of their implementation becomes the property of not only one country.

The consequence of the US's leading position in the world economy is the large number English and American terms in economic vocabulary terms of many languages, German, Russian and Tatar languages are no exception: Clearing $\mathrm{n}$ - clearing - clearing, Futures pl - futures - futures, Marketing n - Marketing - Marketing, Distributor $\mathrm{m}$ - distributor - distributor.

As S.V. Grinev-Grinevich (2008) thinks, borrowing contributes to the improvement and development of the 
language, making it "accurate in expression, emotionally expressive and stylistically diverse" (Grinev-Grinevich, 2008). The formation of terminology of many national languages has "one common feature - a tendency to borrow from a wide range of rather limited range of developed languages" (Grinev-Grinevich, 2008).

Among international terms there are words that have a narrow scope of distribution, limited by the scope of one professional specialty. These terms shall have the opportunity to expand the scope of use with the spread in the association of the relevant knowledge or production (Belchikov, 1959).

\subsection{Hypothesis of Research}

Foreign vocabulary in economic terminology of the German, Russian and Tatar languages is characterized by common areas of borrowing as well as by non-comparable sources of borrowing.

For a comparative description of the international vocabulary in economic terms of the German, Russian and Tatar languages it is necessary to dwell on such aspect as the time of borrowing. The chronological aspect is directly related to another type of classification by language - the source of borrowing.

In connection with the process of borrowing in the terminology state of economics in the German, Russian and Tatar languages, it is relevant to identify the facts of mutual influence and mutual enrichment of compared languages.

All foreign-language concepts are in the process of adaptation in the terminology system of economics of compared languages.

In the classification of loanwords by the degree of assimilation linguistics sometimes resorts to the terms barbarisms and exoticisms. These lexemes are available in the material of this study.

\section{Materials and Methods}

The data for this study are the terms of the economy of the German, Russian and Tatar languages, taken from bilingual dictionaries "Russian-Tatar dictionary of economic terms" (Gazizova, 1999), "New Russian-German Dictionary of Economics" (Salischev, 2000), 6-volume reference-dictionary of economics "Gabler Wirtschaftslexikon" (2004) and others.

This comparative study used comparative and structural-semantic methods as well.

\section{Results}

In the international vocabulary of any terminology a special place is taken by terms of the ancient Greek and Latin origin, or words composed of the Greek and Latin morphemes. Greek and Latin morphemes have great potential in the designation of the international character of the concepts, they are one of the "primary source of any terminology" (Volodina, 1993). The peculiarity of such terms is that they convey the meaning "by the constituent terminological elements" not resulting in polysemy (Danilenko,1971).

Greek and Latin morphemes form a significant group among the economic terms of the German, Russian and Tatar languages. Terminology international vocabulary of economics includes both words and phrases.

A feature of Greek and Latin terms in the terminology of economics is that they penetrated into comparable languages via other languages. For example, in the Russian language, these concepts came through Poland in the 17th century, and later through the Western European languages: devaluation, inflation, blanquism, emission, emitter, license. In the terminology of the Tatar language they came through the Russian language. The following Greek and Latin terms are borrowed from French into German: Emission $f$, Blanquismus m, Bonität $f$, Fusion $f$, Ökonomie f, Deflation f, Emittent m, Rentabilität f, Lizenz $f$.

In using the international vocabulary in different languages there may appear different kinds of errors. This problem has been repeatedly raised in the works of M.B. Khayrullin. "All the inaccuracies in the field of education, spread of scientific and technical, social and political terms in different in structure and system languages are associated with not taking into account the lexical-semantic, morphological, morphogenetic, word-building capacity of individual language on the issue of their specific paradigmatics and syntagmatics" (Khayrullin, 2000). In the studied terminology the example of national identity in the use of an international language can be a term Produktion $f$, the equivalent of which in the Russian and Tatar languages is the word production (производство) and ж⿻тештеру, but not products (продукиия).

Y. Dwerhagen (1998) paid attention to the problem of congruence and divergence of international economic terms in the German language. In his article, he analyzes international economic terms included in the German language at different times, in terms of their functioning in the legal system in Germany. The author studied the use of such terms in the legislative texts. In contrast to the "old" internationalisms, the words of Italian, French 
and English origin, the use of "new" international economic terms from American English is not always appropriate, and may cause problems. The author of the study as the examples of "new" internationalisms gives the following words: charter, factoring, leasing, franchising. On the one hand, the given terms entered the language, they participate in word-building processes and commonly used by native speakers. But on the other hand, the legal framework of the donor language is not taken into account. Problemless functioning of the "old" internationalisms (Dwerhagen, 1998) explains by the historical correspondence of the legal norms of economic management of the time (Dwerhagen, 1998).

The analysis of terminological economical units of the German, Russian and Tatar languages showed the presence of a small group of inappropriate borrowings among internationalisms. To such group we refer, for example, the term prolongation. Both in the German, Russian and Tatar languages the term can be replaced by means of the native language: Verlängerung $f$ - продление (prodlenie) - туләу вакытын озайнату. We тау give more similar examples: Kreditor $m$ - Gläubiger m, on call- Kredit - Kredit auf Abruf, Konnossement $n-$ See-Schiffsfrachtbrief $m$, Consulting $n$ - Beratung $f$, Distributor $m$ - Eigenhändler $m$, Meeting $n$ - Sitzung $f$, aудит(audit) - проверка (proverka), консалтинг (consulting) - консультирование (konsultirovanie).

The given examples can be explained by the intention to display the "language of prestige". "Foreign words often have the advantage over native synonymous in the way that they certify the socially higher level of a speaker. With these words a person gains his cultural and social authority, asserting his claims to the cultural and business excellence. The use of these words is dictated by a wish to emphasize the high level of education or the knowledge of linguistic etiquette, and other qualities valued in the society today: the level of awareness of the new, modern, technically foreground" (Rosen, 2000).

In the terminology borrowing in the sphere of economics of the German, Russian and Tatar languages there are the following comparable areas whose origin can be divided into:

-Latin and French:

Marge f-маржа, Reserve $f$ - резерв(reserv) - резерв, Honorar $n$ - гонорар (gonorar) - гонорар, Arbitrage fарбитраж(arbitrage) - арбитраж, Audit m-ayduт(audit) - aydum, Akzisef-aкциз(aktsiz) - акииз, Tariffmapuф(tariff)-тариф, Aktie f-акция (share) - акцฺия.

-Italian borrowings:

Giro $n$-жиро(jiro)(endorsement) - жиро, Disagio $n$ - дизажио(dizagio) - дизажио, Konto $n$, netto - нетто (net) - нетто, brutto - брутmо (gross) - брymmo, Bankrott $m$ - банкрот (bankrupt), Tratte $f$ - mpamma (draft) - тратта, Kasse f-касса (cash desk) - касса, Bilanz f-баланс - баланс, Bankf-банк - банк.

-Angloamericanisms:

Hedging $n$ - хеджинг - хеджинг, Dealer $m$ - дилер - дилер, Factoring $n$ - факторинг - факторинг,

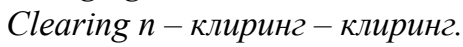

The presence of Italian vocabulary in the comparable languages, mainly related to banking, is explained by the emergence of the world's first bank in Italy. Borrowings from the Italian language in the economic vocabulary of the German language appeared in the Middle Ages: Giro, Skonto, Konto, Tratte (Dwerhagen, 1998). In the following centuries the language of the German economics continued to enrich with the words of Latin, French and Italian origin. In 1950, the first place in the German language by the number of borrowings was held by the Latin language, followed by the French language. English at the time was only the third. This state of affairs was typical for most terms of trade. Angloamericanisms gradually began to enter the terminology of the German economics in 1958, and eventually the process of borrowing from American English became highly developed. In the German studies the issue of angloamericanisms impact on different spheres of economics has been numerously researched. The overview of theoretical studies on this issue is found in the work by A. Efferents and W. Fit. In their work the authors refer to the studies by such authors as A. Stiven, B. Carstensen and H. Galinsky, W. Allane, H. Fink, D. Duckworth, B. Engels, H. Meyer and others (Dwerhagen, 15-27). Borrowings from the American English into the German economic terminology currently occupy the leading position, so that the professors of economics departments say now about the Americanization of this terminology.

Terminological borrowings in the trade and financial sphere penetrate into the Russian language from the English, German, French and Italian during the era of Peter the Great. Economic concepts of these languages continue to replenish the studied terminology until the 19th century. The borrowings of that time included such terms as: capital, credit, tariff, banker, cashier, bank, shareholder, balance. At the turn of the 19-20 century, English plays a special role in replenishing the lexical structure of the economy of the Russian language: meeting, business, capital, trust, import, export. The emergence of a large number of foreign language concepts, 
associated mainly with the social and economic terminology, L.P. Krysin explains by the "development of capitalist relations in Russia" (Krysin, 2008).

Non-comparative group of borrowings in the economic terminology vocabulary of the Tatar language is the vocabulary of the Arabic and Persian origin: сәясәт, икьтисад, фаиз, ииркәт, сәудә, хакимият.

Arabic and Persian borrowings influenced the Tatar language to the second half of the 19th century. As rightly observed by F.S. Faseev, the Arabic and Persian lexemes had the same function as the Greek and Latin and other Western European borrowings in the Russian language (Faseev, 1969).

From the 80 s of the 20th century in connection with certain social and political changes in the Russian society, some Arabic borrowings ousted at the time, began to gradually return to use, and historic words became neologisms, at that the Arabic and Persian borrowings defined the basic concepts of economics, for example, икьтисад, сәндгать. I.I Siraziev writes that the replacement of some Russisms by the "returned" Arabic borrowings could seem unfamiliar, but over time, in his opinion, "they will be included in regular use since the sound structure of the modern language allows easily to adapt most of the units of the Arabic language almost with no significant change" (Siraziev, 2000).

The above mentioned foreign-language concepts coming from European languages, are reflected in the terminology of economics of the Tatar language through the mediation of Russian: motivation, cooperation, environment, diversification.

The influence of Europeanisms on the current economic terminology of the Russian and Tatar languages is due to the fact that at the territory of the former Soviet Union the terminology of market relations was practically absent, and the process of borrowing from European languages through the Russian language offers "convenient one-word equivalent" (Kitaygorodskaya, 1996).

In economic terminology of the Russian and Tatar languages there is a small group of borrowings from German: Exchange - Börse f, accountant - Buchhalter m, bill - Wechsel m, rentabel - profitable.

In the late 18th and early 19th century the works of German economists were very popular in Russia. The German Economic vocabulary entered this period mainly as a result of loaning the Russian language in the economic terminology, and through the Russian mediation into Tatar. Mastering the loan terms of the German economy was mainly written. It is namely this period when there emerge such concepts in the Russian terminology vocabulary as wages, value added, overproduction.

The influence of Russian lexemes on the economic terminology of the German language is actualized in the vocabulary of the former GDR (Rosen, 6) and is manifested in Russisms borrowings associated with Soviet reality, as well as in loaning some of the concepts: Sowchos $m$, Sowchose $f$, Bestarbeiter $m$ (Intermediate), Kontrollkommission $f$ (control commission), kommunistisches Verhalten zur Arbeit (communist attitude toward labor).

Economic cooperation between native Russian and Tatar language speakers is the most significant. It is reflected in the nominative units relating to the relevant terminology. The names of monetary units "treasury", "the jackpot", "money" is borrowed to the Russian language from Tatar in the 13th century. Later, in the 16th century the Russian language began to exert a great influence on the Tatar language. Loanwords are embodied in numerous monuments of business writing at the time. Some facts of using loanwords in trade and economic cooperation in the Tatar language are given in the book by E.M. Ahunzyanov. The author writes that the second half of the 19th century in the Tatar language is described not only by the introduction of Russian words and European terms through the Russian mediation, but also by replacing their former Arabic and Persian with Russian names. So, in translation of the "Law of Catherine II" into Tatar, the words factory and plant are explained by the Arabic and Persian кәрханд and сәнәгатьханд. Later they were completely ousted by borrowings, coming from the Russian language. During this period, the language develops the following terms: deposit, payment, fair, fine, flow, bankrupt (Ahunzyanov, 1968).

In the process of adaptation of borrowed terms in economics we allocate two kinds of assimilation: the formal and functional. In its turn, the formal is subdivided into phonetic, graphic and grammar.

Phonetic assimilation is characteristic of borrowing terms in the Russian and Tatar languages. Borrowings from European languages, including angloamerikanisms, as noted above, enter Tatar through the Russian language and undergo all kinds of phonetic assimilation, which include: sound convergence, i.e. regular replacement of the two close sounds with one, for example replacement of short and long vowels in terms of the English language with one sound, due to the absence of such differences in the Russian and, accordingly, in the Tatar languages: Leasing n - leasing; combination of letters of the English language "ea" in this case is a long sound, which is 
replaced in the Russian and Tatar with sound "i"; sound divergence, i.e. replacement of one foreign sound with two, for example the sound $\mathrm{h}$ is replaced by the sounds $\mathrm{g}$ and $\mathrm{h}$ : Holding - холдинг, Hedg - hedge, Hопогаr -gonorar; sound substitution, i.e. replacement of one foreign language sound of receiving language, for example the replacement of the solid sound $\mathrm{m}$ of the English language with a soft sound $\mathrm{m}$, for example, meeting митинг;

The returned Arabic and Persian borrowings in economic terms of the Tatar language do not cause difficulties in terms of phonetic adaptation. Their phonetic form is familiar to the language for many years. Among such assimilated concepts early borrowings from the Italian and French languages in the German, Russian and Tatar languages can also be considered: Aktie $f$, Bilanz $f$, Tratte $f$, Konto $n$, share, excise, balance.

Terms, which are "foreign words" from the Latin, French and Italian origin entered the compared languages long time ago, most of them are not perceived by native speakers as "the original borrowings" and therefore do not represent the complexity in terms of pronunciation.

Modern borrowings in the German economics, in terms of phonetics, are assimilated in the original form. It primarily relates to angloamerikanisms. This fact is due to a good command of the English language among population.

The next type of adaptation is a graphical assimilation, i.e. reflection of a graphical form of a foreign language term by means of receiving language. This process is accompanied by the graphic changes in writing terms, if the receiving language is used by different from the language of the source graphics system. Graphic renewal takes place among modern borrowed English terms in the Russian and Tatar languages. Graphic renewal is accompanied by trans-phonation or transliteration (Grinev-Grinevych, 2008). In the first case it goes about the transfer of the sound sequence of the source language by graphical means of the borrowing language, for example: хеджинг - hedging. In the second case the alphabetic sequence of the source language is transferred by means of the borrowing language, for example: consulting-консалтинг. There are mixed cases, such as the transmission of English borrowings with a consonant $\mathrm{r}$-in words marketing, service (маркетинг, сервис).

Arabic and Persian borrowings in the Tatar language, Italian and French borrowings in the German and Russian languages recorded their writing much earlier. Modern borrowings in German retain the English graphics, but nouns at that are written with a small letter. S.V. Grinev-Grinevich believes that the phonetic assimilation of oral borrowing proceeds easier than that of written one because of the inhibitory effect of foreign language writing (Grinev-Grinevich, 2008).

Grammatical assimilation involves the incorporation of borrowed words in gender, number and case system. In establishing the gender two factors are usually taken into account - the meaning of the word and its form, especially the inflexion. In economic terminology of the compared languages currently in establishing gender a leading role is played by the form of the borrowed word.

Thus, in economic terms of the Russian language at present a large group of borrowed words is formed by loan words having a hard consonant inflexion in the nominative case. Such words by the grammar rules of the Russian language are masculine: the fee (gonorar), rally (meeting), dealer, leasing. Terms ending in $-a$ are feminine: Avista, scam (afera). Neuter words have the final -o, for example: collection, agio, aviso.

Borrowings in the Russian language also acquire the case endings and take the category of number by attaching inflexions, with the exception of words ending in a vowel - $O$.

As it is known, in the Tatar language there is no category of gender, so they attach to terms - "foreign words" case affixes, such sistemaga, brokerdan.

When choosing a grammatical gender of a foreign borrowing in the German language suffix becomes a crusial factor. Angloamerikanisms with suffix -ing are neuter nouns in German, for example: Meeting n. Suffixes borrowed from other languages, such as French -tät, -tion are feminine suffixes in German and suffixes -eur, -är are masculine: Auktion $f$, Bonität f, Kontroleur m, Millionär m.

The borrowed term undergoes graphic, phonetic, grammatical changes, but assimilation ends only when it becomes a part of the lexical system. Therefore, along with the formal signs of assimilation, discussed above, the functional ones, i.e., lexical and semantic changes in the use of borrowings are isolated. Lexical and semantic assimilation includes the recognition of the borrowed term and its regular use, as well as compatibility with the native words. In economic terms of the compared languages foreign-language terms are often borrowed with one special meaning. Thus, the word икътисад (iktisad) (economics) in the source language has another meaning economy. In the Tatar language, this meaning is rendered by the original word хуќaлblк(huќalyk). The term Business $n$ - business - business in the German, Russian and Tatar economic terminology has one lexical 
meaning, in English this word has three meanings.

However, it should be noted that the lexical-semantic assimilation is a long process that takes place after all types of formal assimilation and is completed with differentiation of the meaning of the borrowed term in relation to its meanings in the source language, as well as the words in the borrowing language.

The special feature of the studied economic terminology in the German, Russian and Tatar languages is the fact that numerous international terms are characterized by word-building activity and are used as construction material for creating new terms. For example: Holding $n$ - Holdinggeschäft $f$, Holding-Bank $f$, Clearing $n$ Clearingabkommen $n$ - multilaterales Clearing, аренда - арендатор (lease-leaser), лизинг - лизинговый (leasing), фрахт - фрахтователь (freight-affreighter), дебитор - дебитор (debtor) бурычы,, банкрот (bankrupt) - банкротлык - дәүләт күләмендәге банкротлькк. Such word-building is called in the linguistic literature hybrid words or hybrids. Derivational activity of "foreign words" is presented in the scientific literature as one of the most important features of their functional assimilation. However, the inclusion of such hybrid words into the category of borrowed terms, in our opinion, is not correct, as it is contrary to the understanding of borrowing as the process of one language linguistic model reproduction in the lexical system of another language and it does not consider the involvement of foreign words in the scope of word building of the borrowing language.

Loanwords in economic terms can be described by the terms barbarisms and exoticism.

Barbarisms do not cause any associations with foreign realities and can be translated into national languages. However they are used in order to facilitate international understanding.

In our study such terms are presented by the following borrowings: netto - нетто, brutto - брутто - брутто, Force тајеr - форс-мажор - форс-мажор, fot - фот - фот, fob - фоб - фоб, for - фор - фор, fio - фио фuo.

Exoticisms unlike barbarisms clearly convey belonging of a word or term to a particular culture. In our study units of money can be attributed to such: Euro - евро - евро, Dollar - доллар - доллар, Јепе - иена - иена.

\section{Discussions}

Before proceeding to the analysis of loanwords in terminology of the German, Russian and Tatar languages, it is necessary to address some of the theoretical research of the problem of borrowings.

There are many classifications of borrowings that characterize 1) time, 2) subject correlation, 3) a method of penetration from one language into another, 4) sources, 5) spheres, 6) structural features of this linguistic phenomenon.

In this case, we adhere to the traditional understanding of the phenomenon, namely borrowing from other languages, referred to under the above classification as "external", as borrowing from the common language and another language is not a phenomenon of the same order (Superanskaya, 2009).

Many linguists, studying the process of borrowing in different terminology systems define it as internationalization and lexical units, resulting from this process are called internationalism ( Danilenko, 1971; Volodina, 1993; Superanskaya and others 2009).

These lexical units, according to the opinion of the above mentioned linguists can not be fully considered as borrowings, as "They differ from ordinary borrowings in the way that they reflect the concept of international importance and have a wide range of distribution (at least in three unrelated languages). International vocabulary, in their view, a historical phenomenon that emerged and grew under certain conditions, namely in the period of the "new history", as a result of cultural and historical interaction of people in the most stressful and turbulent period of human history" (Belchikov,1959).

\section{Conclusion}

Economic terminology of the German, Russian and Tatar languages is enriched as a result of borrowing vocabulary of other languages.

Among internationalisms in the study of terminology a special place is taken by Greek and Latin borrowings. Other sources in the formation of common international economic terminology are terminological concepts of Italian, French and English.

The returned Arabic and Persian borrowings refer to non-comparable to other languages area of borrowings in economic terminology of the Tatar language.

Terminology economic borrowings in the German language in their overwhelming majority retain the sound 
form of the borrowed language. In addition, the borrowed economic terms obtain in the analyzed languages graphical and grammatical form, later being actively involved in word-building processes.

In foreign vocabulary of the studied terms of the compared languages there are barbarisms and exoticisms, promoting the facilitation of international contacts in the economic sphere.

\section{Acknowledgments}

The work is performed according to the Russian Government Program of Competitive Growth of Kazan Federal University

\section{References}

Akhunzyanov, E. M. (1968). Russkie zaimstvovaniya v Tatarskom yazyke. Kazan: KGSU, 367.

Arntz, R., Picht, H., \& Mayer, F. (2009). Einführung in die Terminologiearbeit: Studien zu Sprache und Technik. Hildesheim, Zürich, New York: Georg Olms Verlag, 331.

Belchikov, Yu. A. (1959). Internationalnaya terminologiya Russkom yazyke. Moskva.: Uchpedgiz, 78.

Danilenko, V. P. (1971). Lexico-semanticheskie i grammaticheskie osobennosty slov-terminov. issledovanoya po Russkoy terminologii. Moskva: Nauka, 7-78.

Dwerhagen, J. (1998) Kongruenz und Divergenz der Bedeutung von fremdsprachigen Begriffen und ihrer Übersetzung in der internationalen Rechts- und Wirtschaftssprache. Sprache und Information in Wirtschaft und Gesellschaft, XI. Jahrestagung der internationalen Vereinigung "Sprache und Wirtschaft", 164-172.

Efferenz, A., \& Vieth, U. (1996). Das Verständnis wirtschaftsspezifischer Anglizismen in der deutschen Sprache beim Unternehmen. Frankfurt am Main: Peter Lang GmbH, 196.

Faseev, F. S. (1969). Tatar telende terminologiya. Kazan, 200.

Gabler Wirtschaftslexikon Taschenbuch- cassette mit 6 Bd. Wiesbaden; Dr. Th. Gambler GmbH 2004.

Gazizova, F. M. (1999). Russko-Tatarsky slovar' economicheskikh terminov. Kazan: Rannur, 448.

Grinev-Grinevich, S. V. (2008). Terminovedenie. Moskva. Academia, 304.

Khairullin, M. B. (2000). Problemy razvitiya leksicheskoy systemy Tatarskogo literaturnogo yazyka. Kazan, 202.

Kitaigorodskaya, M. V. (1996). Sovremennaya economicheskaya terminologiya. The Russkiy yazyk v kontse 20 stoletiya. Moskva: Yazyki Russkoy cultury, 162 - 235

Krysin, L. P. (2008). Slovo v sovremennykh tekstakh I slovaryakh. Ocherki o Russkoy leksike and lexicographii. Moskva. Znak, 284.

Leichik, V. M. (2009). Terminovedenie: predmet, metody, structura. Moskva: Librocom, 256.

Rosen, E. V. (2000). Na poroge 21 veka. Novye slova i slovosochetaniya v Nemetskom yazyke. Moskva. Manager, 192.

Salischev, V. A. (2000). Novyi Russko-Nemetskyi slovar'Economiki. Moskva. RUSSO, 608.

Schmitz, K.-D. (2009). Wie finde ich die richtigen Worte? Schöpfung neuer und Auswahl guter Terminologie: Übersetzen in die Zukunft. Berlin: BDÜ, 260-268.

Siraziev, I. I. (2000). Arabsky plast leksiki sovremennogo Tatarskogo yazyka (Kandidatskaya dissertatsiya). Kazan: KGU, 177.

Superanskaya, A. V., Podolskaya N. V., \& Vasiljeva N. V. (2009). Obschaya terminologiya: voprosy teorii. Moskva: Librocom, 248.

Volodina, M. N. (1993). Nationalnoe i internationalnoe v processe terminologycheskoy nominatsii. Moskva. Moskovsky Universitet, 111.

Wright, S. E., \& Budin, G. (1997/2001). Handbook of Terminology Management. Volume 1 (1997): Basic Aspects of Terminology Management; Volume 2 (2001): Application-oriented Terminology Management. Amsterdam/Philadelphia: John Benjamins, 165. http://dx.doi.org/10.1075/z.htm1

\section{Copyrights}

Copyright for this article is retained by the author(s), with first publication rights granted to the journal.

This is an open-access article distributed under the terms and conditions of the Creative Commons Attribution license (http://creativecommons.org/licenses/by/3.0/). 